\title{
Three decades of land use changes in the region of Madrid and how they relate to territorial planning
}

\author{
M. Gallardo ${ }^{1}$ and J. Martínez-Vega ${ }^{2}$ \\ ${ }^{1}$ Department of Geography. University of Concepción. Victor Lamas 1290, Casilla 160-C, Concepción, \\ Bíobío (Chile), +56041-2201586, mgallardob@udec.cl; ${ }^{2}$ Institute of Economy, Geography and Demography, \\ Spanish National Research Council. (IEGD-CSIC). C/Albasanz, 26-28. Madrid 28037 (Spain), \\ javier.martinez@cchs.csic.es
}

\begin{abstract}
In recent decades, the region of Madrid has experienced extensive changes in land use-land cover (LULC). Most of these changes are related to an increase in artificial areas (urban, industrial, commercial and transport) and abandonment of agricultural uses. The general guideline for regional management has been disregarded and the legal framework overstepped, allowing such changes to go ahead unchecked. Using four maps for different points in time, 1982, 1990, 2000 and 2006, LULC dynamics are analyzed and the changes are related to Madrid regional policies. The IDRISI Land Change Modeler (LCM) is used in order to quantify the changes and find out where they took place. The results show that artificial areas doubled in size between 1982 and 2006. Changes were concentrated around the Madrid metropolis and around the main road network, with an increase in urban sprawl and with new, small urban patches in mountain areas of high scenic beauty. These fast and extensive changes were largely made possible by public disinterest and limitations in land and natural resource conservation mechanisms and in housing market regulation.
\end{abstract}

Keywords: Land use-Land cover change; regional planning; urban development; urban sprawl; Madrid.

\section{Introduction}

Landscape should be a major issue of political interest (Gulinck et al, 2001). Land uses can operate as climate regulators and support different ecosystems. They are the result of interactions between biophysical and socio-economic processes (Turner et al, 1983), and play a key role in economic and social development on local, regional and even global scales.

For these reasons, land use/land cover (LULC) change should be considered in strategic planning and environmental impact studies. Poor management of LULC may result in negative impacts, such as an increase in greenhouse gases (Barson et al., 2004; James, 2012), loss of agricultural land (Wu et al., 2006), biodiversity loss, habitat destruction (Shalaby \& Tateishi, 2007), deforestation (Mas et al., 2004) or forest decline (Lasanta \& Vicente-Serrano, 2012), degradation and fragmentation of landscapes (Ayad et al., 2005), degradation of soil quality (Dunjó et al., 2003; Ali, 2006; Cebecauer \& Hofierka, 2008), formation of quarries and sabkhas (Abd El-Kawy et al., 2011), increase in floods (Dewan \& Yamaguchi, 2009), urban growth (Wu et al., 2006; Xiao et al., 2006), urban heat islands (Zhang et al., 2013), urban sprawl (Bhatta et al., 2010), etc.

A vast number of studies and projects related to LULC change have been carried out (Gulinck et al., 1993; Holbrook \& Tudor, 1993; EEA, 2002). In Europe, one of the most interesting programmes is CORINE (Coordination of Information on the Environment) and its Land Cover project, which began in 1985. Its objective is to gather information on the state of the environment in European Union (EU) Member States in order to guide and ensure inclusion of the environmental dimension in community policies. With data from three years (1990, 2000 and 2006), currently being updated to include 2012 , this project provides standardized information on different points in time and makes it possible to carry out further comparative studies between different countries or regions of the EU (Büttner et al., 2000; Feranec et al., 2000; 2007a; 2007b; 2010).

Most LULC change studies are based on a cross-tabulation matrix or transition matrix (Bell, 1974; Green et al., 1994; Cousins, 2001; Chen, 2002; Briceño, 2003; Cardille \& Foley, 2003; Dupuy et al., 2007; Peña et al., 2007; Camacho et al., 2008; Fraser et al., 2009; Mallinis et al., 2011) and provide information on transitions between land categories. But, from the point of view of planning, in addition to quantifying changes, it is important to also note where they take place.

Recent publications have already paid attention to the biggest transformations occurring in the region of Madrid in the past few years, particularly regarding fast urban development and the abandonment of agricultural areas (Aldana, 2005; Plata Rocha et al., 2009; Ruiz Benito et al., 2010). This fast urban development has placed Madrid's protected areas at risk; e.g., Romero-Calcerrada \& Perry (2004) and Pérez-Hugalde et al., (2011) noticed an increase in artificial land uses in 
the Special Protection Area "Encinares del rio Alberche y Cofio" between 1984 and 2006; and Hewitt \& Escobar (2011) noticed urban sprawl inside the natural protected area of the Guadarrama river between 1990 and 2006.

As Madrid is a highly urbanized region (Ministerio de_Fomento, 2015), it is very important, especially for housing market regulation, to know and understand its spatial planning and how this relates to LULC changes and defines the destination and use of different areas.

Therefore, the objectives of this study are: (a) to study the dynamics regarding different land uses, using four maps for different points in time, 1982, 1990, 2000 and 2006; and (b) to relate the LULC changes to Madrid's regional policies.

Using cross-tabulation matrix analysis, we quantify the changes in terms of gains, losses, swap, net change and total change and, by overlaying the maps, we see where these changes took place. Therefore, two questions are answered: how many changes are registered, and where the changes are located.

\section{Study site}

The study site is the Region of Madrid (Figure 1). The region covers an area of $8,026 \mathrm{Km}^{2}$, has a population of $6,495,551$ inhabitants and is the most densely-populated region in Spain. It generates 17\% of the country's GDP and is the second most important industrial center of Spain. In addition, it is the main node for air travel between Europe and Latin America.

Preserved forests and public utility forests play a protective role for soil and water resources and cover $9 \%$ and $12 \%$ of the territory, respectively. Natural protected areas occupy \% (MAGRAMA, 2015), while forest lands cover $48 \%$ of the regional area (CORINE Land Cover Map 2006).

In the last two decades and before 2008, Madrid has experienced rapid economic growth which has led to large territorial transformations and extensive LULC changes, many of them linked to the road network. This artificial growth has had territorial impacts throughout the region (Plata Rocha et al., 2010). In 2010, the former Observatory of Sustainability in Spain (OSE) published a report stating that the period between 2000 and 2006 could be considered to have seen the most extensive urban and infrastructure development in the history of Spain, and Madrid is one of the regions in which this process was particularly intense.

The region of Madrid should be considered a representative case of multidimensional urban growth in Europe. It provides an example of complex expansion of a city core and Larger Urban Zones (LUZ) in the Mediterranean region (Arribas-Bel et al., 2011), that is, a particular form of sprawl.

Madrid's spatial planning can be divided into regional planning and municipal planning; regional plans are approved by the Region and affect the entire territory, while municipal plans are approved by the towns and municipalities and are binding locally, although their consequences often go beyond their own territory. The region is subdivided into 179 municipalities. A detailed study of the planning of each municipality falls outside the scope of this research, which is on a larger scale. We focus on regional instruments, emphasizing urban planning.

\section{Data and methodology}

We used four LULC vector maps for our analyses:

- A vegetation and land use map of the Region of Madrid, from 1982, provided by the Ministry of Environment and Territorial Planning of the Region of Madrid

- $\quad$ Three CLC maps for 1990, 2000 and 2006, downloaded from the website of the European Environment Agency.

- CLC covers most of Europe. It is on a 1:100,000 spatial scale, with a minimum significant area unit of 25 ha and a minimum width of $100 \mathrm{~m}$. It has a hierarchical legend covering up to five levels of LULC classes.

The 1982 LULC map has a different spatial resolution and a different thematic legend, so we generalized and standardized it, and reclassified the legend from the 68 categories covered by the data to the 30 categories of CLC level 3 that are to be found in the Region of Madrid. We selected level 3 as the CLC 2006 legend did not offer more detail.

Our reclassification used Landsat 5 TM for 1984, a base map for 1982 and CLC for 1990 as support. Some categories were broken down and other categories were mapped. For example, the Urban uses category was broken down into 10 different CLC categories (continuous urban fabric; discontinuous urban fabric; industrial or commercial units; roads and rail networks and associated land; airports; mineral extraction sites; dump sites; construction sites; green urban areas; and sport and leisure facilities). Vineyards, streams, wetlands, etc. were not represented on the 1982 LULC map and had to be mapped; the Landsat 5 TM for 1984 and a national base map for 1982 were used. After reclassification, spatial 
generalization converted the 1982 LULC map from a scale of 1:50,000 to 1:100,000. For this purpose, we eliminated polygons under 25 ha and linear shapes under $100 \mathrm{~m}$ in width. We also eliminated all slivers, checking them one by one, as the boundaries of the 1982 LULC map did not overlap with the CLC boundaries.

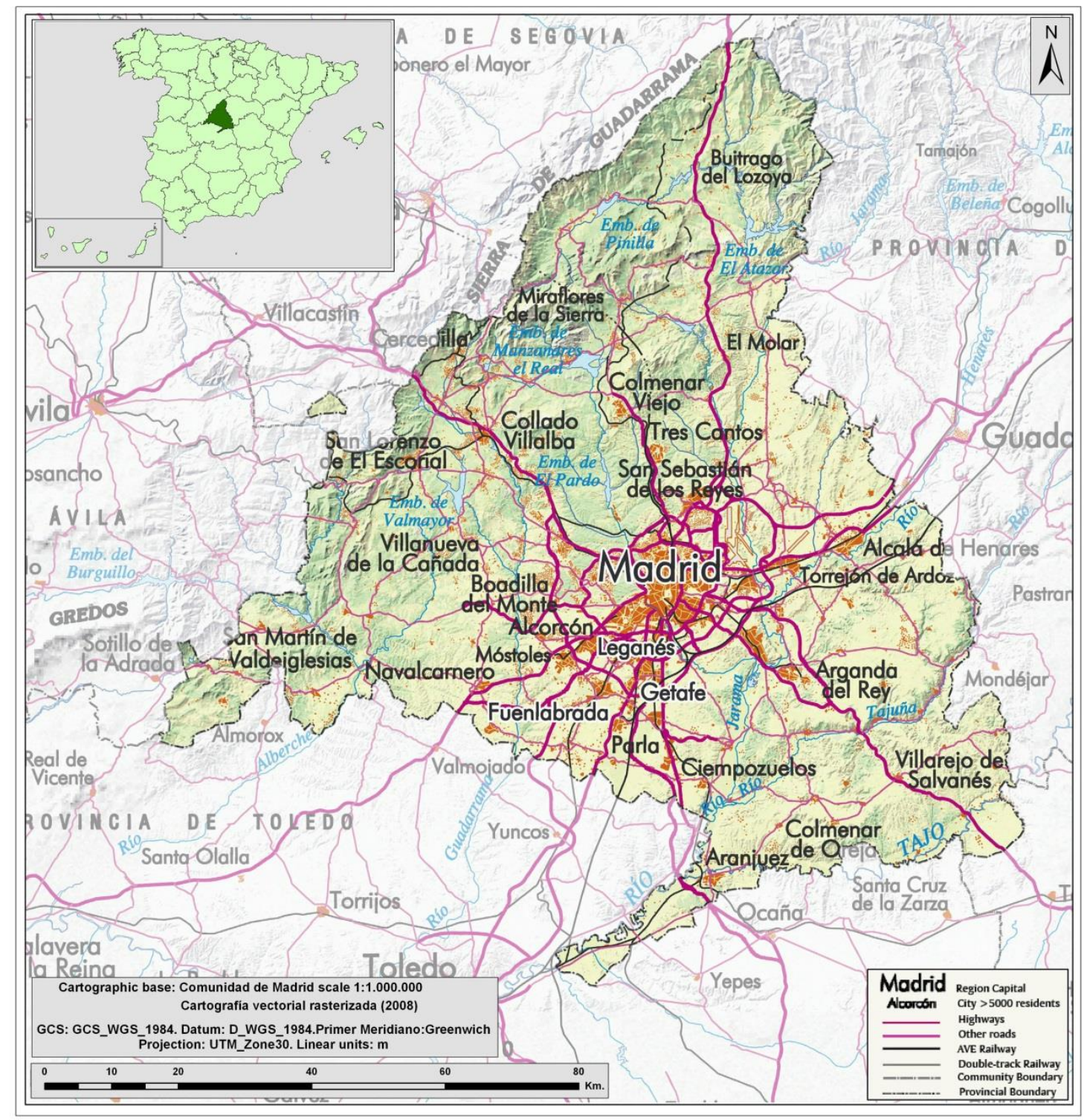

Figure 1. Location of the study area

We found rare or impossible transitions between certain categories, such as from urban areas to arable lands. Researchers including Catalá Mateo et al. (2008), Hewitt \& Escobar (2011), Barreira et al. (2012), Gallardo \& Martínez-Vega (2012) or Díaz-Pacheco \& Gutiérrez (2013) had already noticed these errors in CLC and in the region of Madrid. These errors were corrected as they were generating false LULC change values. For this purpose we used remote sensing data and aerial photography, that is, Landsat data for 1987 and ortophotos for 1999 and 2002; these data were the nearest to the available LULC year maps.

LULC changes were analyzed using level 2 of the CLC legend (there are 13 different LULC categories in the Region of Madrid, see table 1). The four coverage maps were converted to a raster dataset with a 50x50 grid cell resolution. 


\section{Table 1. CLC level 2 categories in the Region of Madrid, Spain.}

\begin{tabular}{lcl}
\hline Order number & CLC code & Denomination \\
\hline 1 & 11 & Urban fabric \\
2 & 12 & Industrial, commercial and transport units \\
3 & 13 & Mine, dumps and construction sites \\
4 & 14 & Artificial non-agricultural vegetated areas \\
5 & 21 & Arable land \\
6 & 22 & Permanent crops \\
7 & 23 & Pastures \\
8 & 24 & Heterogeneous agricultural areas \\
9 & 31 & Forest \\
10 & 32 & Shrub and/or herbaceous vegetation association \\
11 & 33 & Open spaces with little or no vegetation \\
12 & 41 & Inland wetlands \\
13 & 51 & Continental waters \\
\hline
\end{tabular}

The IDRISI Land Change Modeler (LCM) was used. This allows LULC changes in the past to be analyzed, assessing changes in graphic and cartographic form, providing analysis of gains, losses, net changes, exchanges and/or transitions between two time data sets and also cartographically providing the location of these changes.

\subsection{Cross-tabulation matrices.}

Quantification of LULC changes was carried out using cross-tabulation matrices. This method was proposed by Pontius et al. (2004) to detect the most significant changes occurring between two points in time. Three different periods were analyzed: a) 1982-1990; b) 1990-2000; and c) 2000-2006.

Figure 2 shows the definition of the matrix.

LULC categories at time 1 are represented in rows, and categories at time 2 are represented in columns. Pij denotes the proportion of the landscape that experiences a transition from category $i$ to category $j$. Entries on the diagonal indicate persistence. Using this matrix we can obtain different change typologies: a) losses: differences in proportion of landscape in category $i$ between time 1 and time 2; b) gains: differences in the proportion of landscape in category $j$ between time 1 and time 2; c) net changes: differences in the absolute value between gains and losses; d) total changes: the sum of all the gains and losses; and e) swap: differences between total change and net change.

\begin{tabular}{|c|c|c|c|c|c|c|}
\hline & \multicolumn{3}{|c|}{ Time 2} & \multirow{2}{*}{$\begin{array}{c}\text { Total Time } \\
1\end{array}$} & \multirow{2}{*}{ Loss } \\
\hline & & Category 1 & Category 2 & Category 3 & & \\
\hline \multirow{3}{*}{ Time 1} & Category 1 & $P_{11}$ & $P_{12}$ & $P_{13}$ & $P_{1+}$ & $P_{1+}-P_{11}$ \\
\hline & Category 2 & $P_{21}$ & $P_{22}$ & $P_{23}$ & $P_{2+}$ & $P_{1+}-P_{22}$ \\
\hline & Category 3 & $P_{31}$ & $P_{32}$ & $P_{33}$ & $P_{3+}$ & $P_{1+}-P_{33}$ \\
\hline \multicolumn{2}{|c|}{ Total Time 2} & $P_{+1}$ & $P_{+2}$ & $P_{+3}$ & & \\
\hline \multicolumn{2}{|c|}{ Gain } & $P_{+1}-P_{11}$ & $P_{+2}-P_{22}$ & $P_{+3}-P_{33}$ & & \\
\hline
\end{tabular}

Figure 2. Cross-tabulation matrix. Source: Pontius Jr et al. (2004).

\subsection{LULC change maps.}

Among other possible combinations, an LULC change map for each period was drawn up, comparing each pair of data (1982 vs. 1990; 1990 vs. 2000 and 2000 vs. 2006) to show the location of changes. A spatial approach is essential for land management. 
Using CLC level 2, more than 80 different changes were obtained for each period, so the maps were reclassified in order to show the changes more clearly. The most important change in the region of Madrid was the increase in artificial uses. The reclassification is shown in table 2 .

Table 2. Reclassification based on CLC level 2 categories.

\begin{tabular}{llll}
\hline \multicolumn{1}{c}{ CLC level 2 categories } & & \\
\hline 1 & Urban fabric & 1 & Urban fabric \\
2 & Industrial, commercial and transport units & 2 & Industrial, commercial and transport units \\
3 & Mine, dumps and construction sites & 3 & Mine, dumps and construction sites \\
4 & Artificial non-agricultural vegetated areas & 4 & Artificial non-agricultural vegetated areas \\
5 & Arable land & 5 & Agriculture areas \\
6 & Permanent crops & 5 & \\
7 & Pastures & 5 & \\
8 & Heterogeneous agricultural areas & 5 & \\
9 & Forest & 6 & Forest and shrub \\
10 & Shrub and/or herbaceous vegetation association & 6 & \\
11 & Open spaces with little or no vegetation & 6 & Water \\
12 & Inland wetlands & 7 & 7 \\
13 & Continental waters & & \\
\hline
\end{tabular}

\subsection{Change frequencies}

If an LULC class changes, it can transition once or more than once. As we have data for four points in time, a particular LULC category can transition at most three times.

In order to know which LULC categories are most dynamic and where they are located, LULC change frequencies were analyzed and a map of frequencies and typology of changes occurring between 1982 and 2006 was drawn up. Table 3 shows some of the possibilities that can be expected, where each letter (A,B,C,D) stands for a different LULC type and for a different point in time. That is, the first letter correspond to year 1982, second letter to 1990, third letter to 2000 and fourth letter to 2006 . When there is a LULC change, the letter change.

Table 3. Example of number of categories and transitions that can be expected in an LULC change study using four temporal data.

\begin{tabular}{|c|c|c|c|c|}
\hline 1982 & 1990 & 2000 & 2006 & Results \\
\hline \multirow[t]{2}{*}{ LULC A } & LULC B & LULC C & LULC D & Four categories (A,B,C y D) \\
\hline & & & & Three transitions (A-B, B-C, C-D) \\
\hline \multirow[t]{2}{*}{ LULC A } & LULC A & LULC B & LULC C & Three categories (A,B y C) \\
\hline & & & & Two transitions (A-B, B-C) \\
\hline \multirow[t]{2}{*}{ LULC A } & LULC A & LULC A & LULC B & Two categories (A y B) \\
\hline & & & & One transition (A-B) \\
\hline \multirow[t]{2}{*}{ LULC A } & LULC B & LULC B & LULC B & Two categories (A y B) \\
\hline & & & & One transition (A-B) \\
\hline \multirow[t]{2}{*}{ LULC A } & LULC B & LULC C & LULC B & Three categories (A,B y C) \\
\hline & & & & Three transitions (A-B, B-C y C-B) \\
\hline \multirow[t]{2}{*}{ LULC A } & LULC B & LULC B & LULC A & Two categories (A y B) \\
\hline & & & & Two transitions (A-B y B-A) \\
\hline
\end{tabular}

This methodology can also be used to detect errors in mapping, as in the last example in table 3 where there is an ABBA transition, that is, in 1982 the LULC type was A, in 1990 it changed to B, in 2000 it remained at B and in 2006 it changed back to category A. Such LULC transitions are very rare and should be checked. 


\section{Results}

\subsection{LULC change quantities}

The amounts of LULC change for each category are shown in tables 4 and 5. Table 4 shows the percentage of the territory that each LULC category occupies for each year, while table 5 show the losses, gains, swaps and net and total change for each category for the entire period. Both are shown at CLC level 2.

Table 4. Percentage of the territory that each LULC category occupied in 1982, 1990, 2000 and 2006.

\begin{tabular}{lrrrr}
\hline LULC categories & 1982 & 1990 & 2000 & 2006 \\
\hline Urban fabric & 4.85 & 5.18 & 7.02 & 8.20 \\
Industrial, commercial and transport units & 1.49 & 1.75 & 2.74 & 3.43 \\
Mine, dumps and construction sites & 0.63 & 0.61 & 1.26 & 1.79 \\
Artificial non-agricultural vegetated areas & 0.24 & 0.48 & 0.71 & 0.86 \\
Arable land & 28.76 & 27.95 & 24.57 & 23.05 \\
Permanent crops & 2.11 & 2.63 & 2.50 & 2.42 \\
Pastures & 0.60 & 0.57 & 0.54 & 0.55 \\
Heterogeneous agricultural areas & 13.46 & 10.67 & 10.68 & 10.57 \\
Forest & 10.43 & 9.96 & 10.05 & 9.77 \\
Shrub and/or herbaceous vegetation association & 35.95 & 38.78 & 38.51 & 37.94 \\
Open spaces with little or no vegetation & 0.59 & 0.59 & 0.57 & 0.58 \\
Inland wetlands & 0.00 & 0.00 & 0.00 & 0.00 \\
Continental waters & 0.84 & 0.84 & 0.84 & 0.83 \\
Total & 100 & 100 & 100 & 100 \\
\hline
\end{tabular}

Table 5. Losses, gains, net changes, swaps and total changes between 1982 and 2006, in hectares.

\begin{tabular}{lrrrrr}
\hline LULC categories & Losses & Gains & Net change & Swap & Total change \\
\hline Urban fabric & -200 & 26,763 & 26563 & 400 & 26,963 \\
Industrial commercial and transport units & -214 & 15,811 & 15,597 & 427 & 16,025 \\
Mine, dumps and construction sites & -3807 & 13,124 & 9317 & 7614 & 16,931 \\
Artificial non-agricultural vegetated areas & -248 & 5279 & 5031 & 497 & 5528 \\
Arable land & 66,393 & 20,502 & $-45,891$ & 41,005 & 86,896 \\
Permanent crops & -3640 & 6150 & 2510 & 7280 & 9790 \\
Pastures & -1225 & 861 & -364 & 1721 & 2086 \\
Heterogeneous agricultural areas & $-50,527$ & 27,316 & $-23,211$ & 54,632 & 77,843 \\
Forest & $-12,511$ & 7221 & -5290 & 14,443 & 19,733 \\
Shrub and/or herbaceous vegetation associatio & $-28,113$ & 44,001 & 15,888 & 56,227 & 72,114 \\
Open spaces with little or no vegetation & -270 & 125 & -145 & 250 & 395 \\
Inland wetlands & 0 & 0 & 0 & 0 & 0 \\
Continental waters & -11 & 6 & -5 & 13 & 18 \\
\hline
\end{tabular}

The greatest changes were in artificial areas, which saw the greatest growth, and agricultural lands, which saw the greatest losses. Forest areas experienced high swap values. LULC categories showing no change or small change values are inland wetlands, continental waters, open spaces with little or no vegetation, and pastures.

In 1982, almost $45 \%$ of the region of Madrid was agricultural land. Forest areas occupied $47 \%$, and artificial uses occupied slightly more than 7\%. In 2006, artificial areas occupied more than $14 \%$ of the region, agricultural land almost $37 \%$, and forest areas slightly more than $48 \%$, so artificial areas doubled in area, agricultural land registered the biggest losses and forest areas remained constant.

These high LULC change values show that land management focused mainly on urban developments, showing little interest in preserving farmlands or even natural vegetation. 


\subsection{LULC change maps}

The spatial location of the most important changes for 1982-1990, 1990-2000 and 2000-2006, that is, changes from all uses to artificial uses, is shown in figure 3.

In the first period, 1982-1990, LULC changes were spread almost throughout the region. Changes to artificial uses were not numerous and were concentrated around the city of Madrid.

In the second period, 1990-2000, changes were concentrated around the Madrid metropolis and around the main road network, with transitions from agricultural areas and shrubs to urban and industrial and commercial uses. A big patch to the northeast of the metropolis was set aside for the Barajas airport new development. Also, large patches to the north and southeast of the capital indicate new urban developments in peripheral districts. In 1997, the Urban General Plan of the City of Madrid created 15 Urban Action Programs (PAU, legal framework for urban development established by Royal Decree 215/1978, dated June 23), and another 10 PAUs were created around the north, east, southeast, south and southwest regional highways.

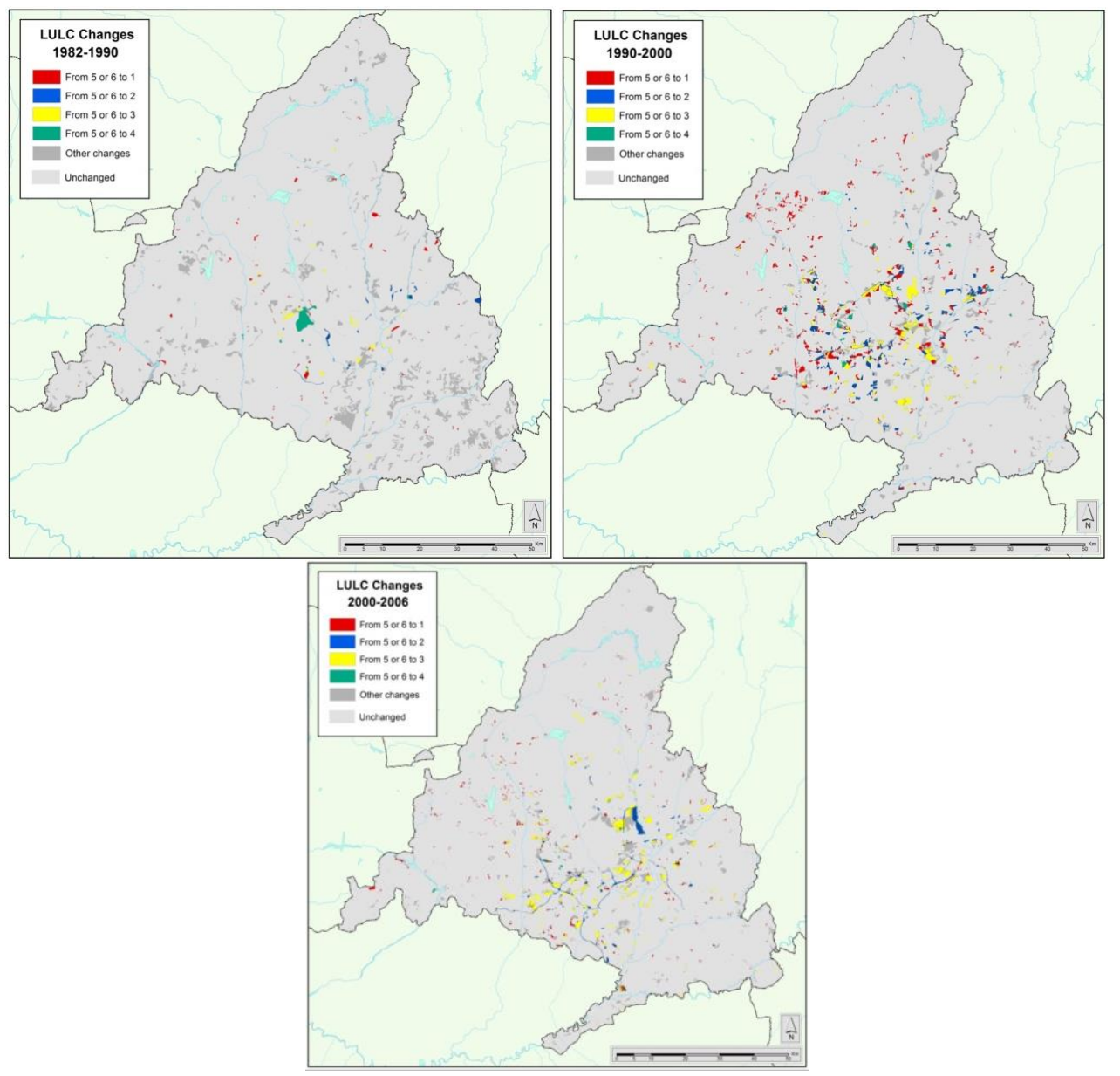

Figure 3. Spatial locations of the most important changes in 1982-1990 (a), 1990-2000 (b), 2000-2006 (c)

With improved access via arterial and circular highways, new industries and large commercial centers were created, especially in the east, south and southwest. In the northwest of the region, small patches of new urban fabric appeared in mountain areas.

Finally, the last period, 2000-2006, showed a similar dynamic to 1990-2000. The artificial growth around the metropolis continued, especially in the south and west. Barajas airport expanded with the new T-4 terminal, and new roads around the 
metropolis were built. The urban expansion process continued throughout the region, especially in the northern and western part of the region, at the expense of forest areas and the most scenic sites.

Figure 3 shows the great investment made in infrastructure, especially in the construction of new highways, neighborhoods, factories and shopping malls during these years. The new urban fabric located in mountain areas $(>300$ ha.) indicates that there was no real concern to protect areas of high natural value.

\subsection{LULC change frequencies.}

Figure 4 shows the location of the LULC categories that were most dynamic between 1982, 1990, 2000 and 2006 , indicating how many changes occurred in each patch. Each letter (A,B,C,D) refers to a different LULC type. The first letter of the legend corresponds to 1982, the second to 1990, the third to 2000 and the fourth to 2006; when A changes to $\mathrm{B}, \mathrm{B}$ to $\mathrm{C}$ or $\mathrm{C}$ to $\mathrm{D}$, this indicates an LULC change. For example, the AABC category in the map means that between 1990 (second letter) and 2000 (third letter) and between 2000 and 2006 (fourth letter) there was an LULC change, as there were changes from A to B and B to C, respectively, but between 1982 (first letter) and 1990 there was no change, as letter A remains.

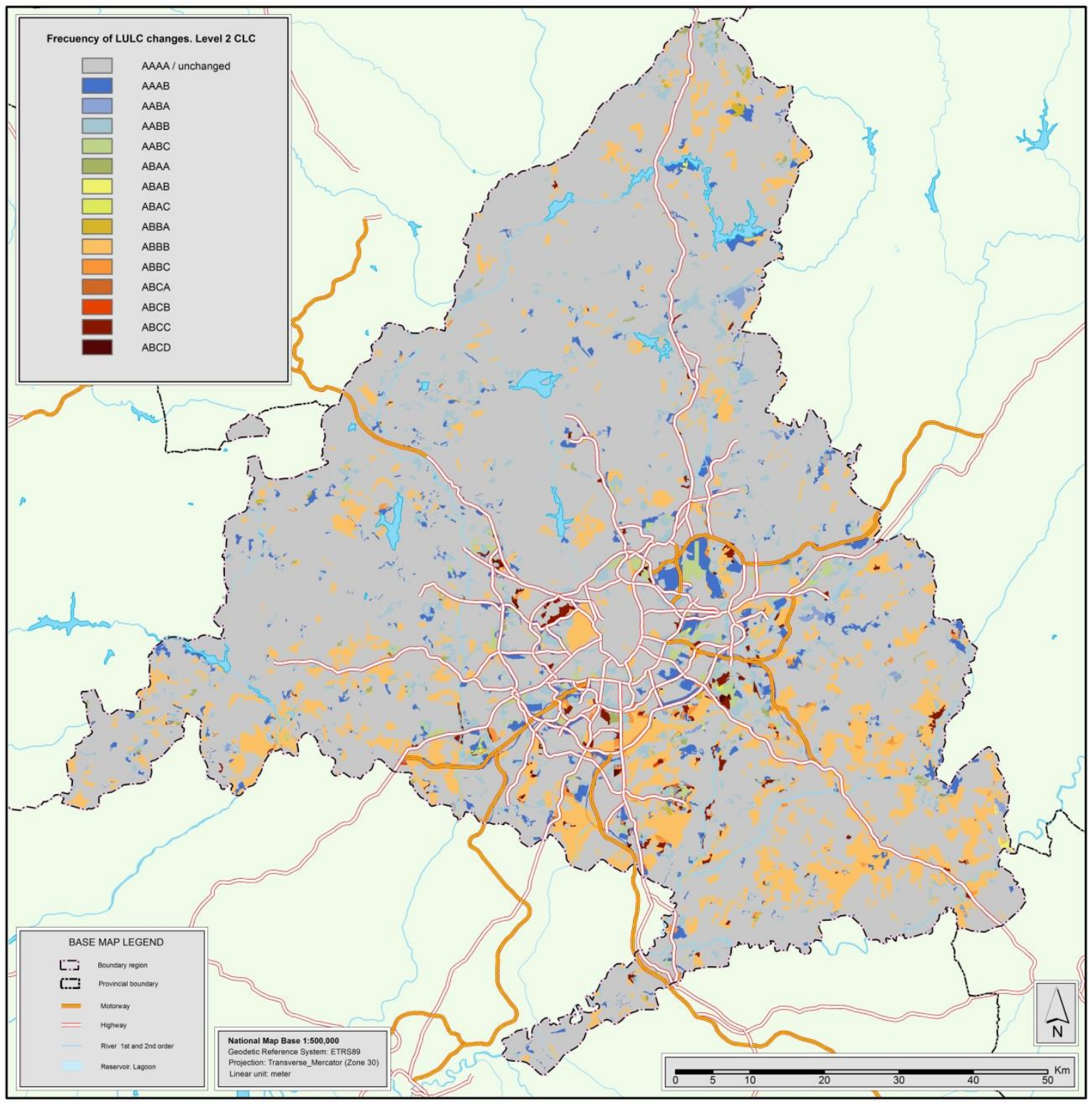

Figure 4. Number of categories involved in LULC changes between years 1982, 1990, 2000 and 2006. 
Figure 4 shows the most common change was from A to B (that is, with just two categories involved). In fact, $18.53 \%$ of the Region of Madrid transitioned from one category to another; this typology can be seen almost all over the territory. Many of these cases refer to marginal arable land spots that were abandoned and subsequently occupied from 1990 by herbaceous and shrub vegetation (ABBB). There were also isolated cases where a reverse process took place with heterogeneous agricultural lands increasing as from 1990 and becoming occupied by arable lands. In the northeast of the capital, agricultural areas were recently taken up by the Barajas airport expansion (AAAB spots).

Almost 3\% of the Region of Madrid transitioned twice. When three categories are involved, i.e. a change from A to B and $\mathrm{B}$ to $\mathrm{C}$, these changes are located around the metropolis and in the south of the region. Some examples (ABCC) are located near the capital; initially, these were agricultural areas that in 1990 were under construction and since 2000 have been urban areas. Similarly, some AABC spots are areas that were under construction in 2000 and are now urban areas or form part of Barajas airport. The involvement of four categories is not usual, i.e. a change from A to B, B to C and C to D. A few cases are registered around the metropolis and, in particular, in the south (just $0.20 \%$ of the Region transitioned three times).

The highest dynamism is located around the metropolis and in the space between the circular highways. In most cases this indicates new urban development plans that went ahead at the expense of agriculture areas and shrubs and pastures.

In summary, throughout the entire period (1982-2006) Madrid's population grew by 1.3 million inhabitants (28\%) (Madrid census), and artificial areas increased by $97 \%$. Some areas, such as construction sites, registered a significant increase $(449 \%)$.

In the past few years, the creation of new transport infrastructure has been a key point in Madrid regional planning. The density of highways and main road networks grew by $218 \%$ and $187 \%$ respectively. Many of these new roads are toll roads. This road development is one of the main factors explaining the expansion of urban, industrial and commercial areas as a result of a substantial improvement in accessibility.

The invasion of forest areas by housing developments and urban sprawl is also leading to an increase in the woodlandurban interface. Between 1982 and 2006, this contact area grew by 46\%, significantly increasing the wildland fire risk.

\section{Discussion}

Methodologically, detecting errors in mapping before performing LULC analysis is essential for obtaining more accurate results. Maps generated using different sources and different methodology, as in our case the 1982 LULC map, should be examined and processed previously. Cartographic generalization and standardization must be carried out, both thematically and spatially, in order to eliminate possible inconsistencies and unexpected results. We decided to include an LULC map dating from the early 1980s in order to analyze the extensive changes that occurred during this decade. It was then that the Region of Madrid became an independent administrative region with responsibility for its own development.

GIS and LULC change maps are useful tools for decision-making (Romero-Calcerrada et al., 2005), especially in the second phase of planning (Bosque \& García, 2000). This phase has a spatial aim - the optimal allocation of particular land uses or occupations in specific places. The results of this second phase may affect the first phase, in which no geographical considerations are taken into account, and may make it necessary to reconsider political and territorial objectives.

As shown in this study, the urban landscape in the region has changed substantially, from a traditional compact city model to a dispersed city model (Munoz, 2003). Various factors explain the rapid and intense urban growth in the region of Madrid (Serra et al., 2014), such as the intensification of urban uses, the young population and naturbanization in recreational spaces (ski resorts) and natural areas (protected areas and reservoirs). Much of this urban development has been built not to live in, but to sell and make capital gains from converting rural land into urban land (Naredo y García Zaldivar, 2008). Environmental cost of this development model has been reflected in a massive consumption of land, water and energy (Méndez, 2013).

Contrary to the assertions made by Moliní \& Salgado (2012), the sealing of land should be considered a problem in Madrid. Our results indicate that this process has been intense and persistent in time, showing an upward trend between 2000 and 2006. Although there is broad urban land available for construction, antrophization has affected not only unprotected areas but also protected areas (Martinez-Fernández et al., 2015) and other high ecological value areas. As shown later, this process has lead several environmental impacts.

Although a general guideline exists for regional management of the territory, the reality is that it has not been taken into account and transfer of planning powers from the State to the regions has worsened the situation (Hildenbrand, 2006). Planning by regional governments has not been successful. In qualitative terms, the Regional Spatial Strategy Plan has not been effectively fulfilled and there has been no coordinated vision of the European Territorial Strategy. Nor has there been 
a cooperation with the regions bordering Madrid. Unilateral urban development conducted by the municipalities has prevailed (Fernández-Muñoz, 2008; Valenzuela, 2011).

Areas with special limitations have not been respected, and land and natural resource conservation mechanisms have not been adopted. Plans for Natural Resources Management have not been approved although they are required for managing Natura 2000 Sites of Community Importance (SCI). SCI in Madrid region includes 45 types of natural habitats with community interest, 9 of which are priorities for European conservation. According to EUROPARC-Spain Data (2013), only $30 \%$ of natural protected areas and $23 \%$ of Natura 2000 network sites in the region of Madrid have a management plan. For example, EUROPARC-Spain Data Annex II (http://www.redeuroparc.org/img/Anuario-2013/Anexo-III_PORN_2013.pdf) show that the Regional Park Curso medio del río Guadarrama y su entorno, Preventive Protection Scheme Soto del Henares and Natural Reserve Regajal-Mar de Ontígola, have approved a regulatory plan but not a management plan. The other protected natural areas and Natura 2000 sites do not have a regulatory plan or management plan legally approved. There have been several initiatives in some SPAs (such as Encinares de los ríos Alberche y Cofio, y Carrizales y Sotos de Aranjuez) but have not been successful. At national level, only 281 management plans have been approved (19\% of Natura 2000 sites). For this reason, the European Commission has opened infringement proceedings to Spain.

In Madrid, managers of protected areas have been unable to protect these areas against urban growth and infrastructure construction. Most of the municipalities included in Natura 2000 have development plans approved prior to the declaration of protected area. It is clear that planners in the region of Madrid aimed to convert this area into the economic engine of Spain and into the innovation center of southern Europe (Fernández-Güell, 2008). All socio-economic indicators are positive. Economic development between 1982 and 2006, has caused a large ecological footprint in the region, but also in its hinterland, and its sustainability has been threatened. LULC changes in the Region of Madrid have been influenced by human activity and in particular by non-compliance with the guidelines for spatial planning. LULC changes involve different impacts, such as high socioeconomic vulnerability (Román et al., 2013), a high risk of forest fires (Chuvieco et al., 2012), and an increase in the woodland-urban interface, this being the main cause of forest fires in the region of Madrid (Vilar et al. 2011). Moreover, urban growth, the construction of large shopping centers and the proliferation of new roads and rail infrastructure have fragmented protected areas and interrupted the main ecological corridors that serve as connectors between core protected natural areas.

The System for the Integrated Assessment of Protected Areas (SIAPA) has been implemented by Rodriguez-Rodriguez \& Martinez-Vega (2013) in the Region of Madrid. Two indicators relating to threats (spatial fragmentation caused by road infrastructure, indicator 38) and socio-economic context (LULC change in past decades, indicator 30) were used for Protected Areas assessment.

Following Rodríguez-Rodríguez \& Martinez-Vega (under review), protected area managers and scientists all agree on the priority of using a fragmentation indicator to evaluate the effectiveness of Protected Areas. Managers consider fragmentation to be the 5th most important indicator and scientists place it in 9th position (1st quartile). There is no unanimity assessing the importance of the LULC change indicator; managers consider it in 22nd place (quartile 2) while scientists consider it in 4th place (1st quartile). Additionally, scientists have proposed the use of a new indicator measuring the degree of coordination between the protected area management body and Public Administrations.

Intense urban growth and the increase in risks have had environmental impacts. It is therefore urgent to implement effective management plans and conservation actions to guarantee the conservation of species and habitats in the Natura 2000 network and not just in the nationally-designated Protected Areas (Martínez-Fernández et al., 2015).

Despite all these LULC changes and urban sprawl, the region of Madrid still has a large forest area and an important natural and landscape heritage within natural protected areas and the Natura 2000 network (Martínez-Vega at al., 2007), which must be properly and effectively managed (Rodríguez-Rodríguez \& Martínez-Vega, 2013).

LULC future scenarios indicate that the situation is likely to become worse. If the trend continues until 2025, artificial areas will occupy $16 \%$ of the territory, that is, more than 134,000 hectares; this growth will expand around the metropolis and the main roads (Gallardo et al., 2015).

In order to mitigate and reverse these problems, some authors (Albrechts et al., 2003; Hall \& Pain, 2006; Fernández Güell, 2008) recommend actions. Amongst thems, we emphasize the following: a) vertical coordination between administrative bodies on different territorial scales (European, national, regional and local) and the private sector; b) horizontal coordination between sectorial policies (urbanism, transport, nature conservation); and c) indicators rather than binding instruments in order to gain flexibility in decision-making. In a baseline scenario, resistance or opposition can be expected from local government if required to give up urban planning. 


\section{Conclusions}

In recent years, the region has experienced extensive dynamic processes. The biggest changes are associated with processes that overlap and are complementary: rapid urban development, growth in the transport system including the huge expansion of Barajas airport and its area of influence, the youth and dynamism of the regional population and proximity to areas of high ecological and scenic value.

Artificial areas growth has not been linked to a population growth. During these years new urban developments have been placed around new roads and new commercial and leisure centers, especially in the south of the metropolis. Between 2000 and 2006, new roads (such as M-45, M-50, R-2, R-3, R-4 and R-5) were built. Barajas airport expansion carried not only the building itself but also an urban growth located in its influence area associated with the airport activity and logistics.

The landscape has been fragmented by growth in the transport infrastructure and by urban sprawl in the northwest of the region; this proliferation of second homes is linked to a desire to be in contact with the nature.

The structure of the urban region of Madrid has become less compact. Over recent decades, the typical, dispersed city pattern of English-speaking countries has been superimposed on the traditional Mediterranean compact city model, an urban sprawl phenomenon that has also influenced other southern European cities.

This process has had several environmental impacts: a large percentage of agricultural land has been destroyed by the expansion of artificial areas, there has been an increase in landscape fragmentation and in the ecological footprint, growth in urban and industrial waste, overexploitation of natural resources, etc.

Nonetheless, the region of Madrid has a large number of natural protected areas of unquestionable ecological value. A major challenge is to ensure the effectiveness of these protected areas, in order to preserve their environmental values. As stated above, the Natura 2000 areas are especially vulnerable. Managers of such areas must pay special attention to these processes in order to avoid impacts that threaten natural resources.

Planning legislation focusing on social, economic and environmental sustainability is urgently needed. Future plans should aim above all to achieve these objectives, and the study of LULC dynamics allows for the analysis of environmental processes.

The methodology presented here is easy to carry out and allows LULC change quantities and spatial trends to be traced. The cartographic results may be useful for land managers and stakeholders as they show the intensity and location of LULC changes. They also indicate if natural and protected areas have been affected. The results should help define new plans for in the near future, in order to preserve certain areas or in order to carry out sustainable land management.

\section{Acknowledgment}

The research leading to these results has been sponsored by a JAE-predoc grant (CSIC) awarded to Gallardo, M.

\section{References}

Abd El-Kawy, O.R., Rød, J.K., Ismail, H.A., \& Suliman, A.S. (2011). Land use and land cover change detection in the western Nile delta of Egypt using remote sensing data. Applied Geography, 31, 483-494.

Albrechts, L., Healy, P., \& Kunzmann, K.R. (2003). Strategic spatial planning and regional governance in Europe. APA Journal, 69 (2), 113-129.

Aldana, A. T. (2005). Cartografía de los cambios en las cubiertas artificiales de la Comunidad de Madrid-España 19871997 (Mapping changes in artificial covers in the Community of Madrid-Spain 1987-1997). Revista Forestal Latinoamericana, 37, 59-86.

Ali, A.M.S. (2006). Rice to shrimp: Land use/land cover changes and soil degradation in Southwestern Bangladesh. Land Use Policy, 23 (4), 421-435.

Arribas-Bel, D., Nijkamp, P. \& Scholten, H. (2011). Multidimensional urban sprawl in Europe: A self-organizing map approach, Computers, Environment and Urban Systems, 35, 263-275.

Ayad, Y. M. (2005). Remote sensing and GIS in modeling visual landscape change: a case study of the northwestern arid coast of Egypt. Landscape and Urban Planning, 73, 307-325.

Barreira, P., González Cascon, V. \& Bosque Sendra, J. (2012). Detección de errores temáticos en el CORINE Land Cover a través del estudio de cambios: Comunidad de Madrid (2000-2006) (Detection of thematic errors in CORINE Land Cover through the study of changes: Madrid, 2000-2006). Estudios Geográficos, 73, 7-34.

Barson, M.M., Randall, L.A., \& Barry, S.C. (2004). Modelling greenhouse gas emissions from land cover change: linking continental data with point/patch models. Mathematics and Computers in Simulation, 64, 329-337. 
Battha, B., Saraswati, S., \& Bandyopadhyay, D. (2010). Urban sprawl measurement from remote sensing data. Applied Geography, 30, 731-740.

Bell, E.J. (1974). Markov analysis of land use change -an application of stochastic processes to remotely sensed data. Socio-Economic Planning Sciences, 8, 311-316.

Bosque, J., \& García, R.C. (2000). El uso de los Sistemas de Información Geográfica en la planificación territorial (The use of Geographic Information Systems in territorial planning). Anales de Geografía, 20, 49-67.

Briceño, F. (2003). Cambios en la cobertura de la tierra en el valle del río Momboy, Estado de Trujillo. (Changes in land cover in the valley of Momboy river, State of Trujillo) Geoenseñanza, 8, 91-110.

Büttner, G., Steenmans, C., Bossard, M., Feranec, J., \& Kolar, J. (2000). Land Cover - Land Use Mapping within the European CORINE Programme, In M.F. Buchroithner, (Ed.), Remote Sensing for Environmental Data in Albania: A Strategy for Integrated Management (pp. 89-100), Kluwer Academic Press.

Camacho, F., Lanjeri, S., Vayá, J., Ruiz, G., Martínez, B., Jiménez, J.C., Alonso, L., \& González-Piqueras, J. (2008). Cartografía medioambiental en tiempo real a partir de datos de teledetección y tecnologías de la información. In L.P. Hernández (Ed.), XIII Congreso Nacional de Tecnologías de la Información Geográfica (pp. 215-225). Las Palmas de Gran Canaria.

Cardille, J.A., \& Foley, J.A. (2003). Agricultural land-use change in Brazilian Amazônia between 1980 and 1995 : Evidence from integrated satellite and census data. Remote Sensing of Environment, 87, 551-562.

Catalá Mateo, R., Bosque Sendra, J. \& Plata Rocha, W. (2008). Análisis de posibles errores en la base de datos CORINE Land Cover (1990-2000) en la Comunidad de Madrid (Analysis of posible errors in CORINE Land Cover database, 1990-2000, in the Community of Madrid). Estudios Geográficos, 49, 81-104.

Cebecauer, T., \& Hofierka, J. (2008). The consequences of land-cover changes on soil erosion distribution in Slovakia. Geomorphology, 98, 187-198.

Chen, X. (2002). Using remote sensing and GIS to analyse land cover change and its impacts on regional sustainable development. International Journal of Remote Sensing, 23, 107-124.

Chuvieco, E., Aguado, I., Jurdao, S., Pettinari, M.L., Yebra, M., Salas, J., Hantson, S., de la Riva, J., Ibarra, P., Rodrigues, M., Echeverría, Azqueta, D., Román, M.V., Bastarrika, A., Martínez, S., Recondo, C., Zapico, E., \& Martínez-Vega, J. (2012). Integrating geospatial information into fire risk assessment. International Journal of Wildland Fire, http://dx.doi.org/10.1071/WF1205

Cousins, S.A.O. (2001). Analysis of land-cover transitions based on 17th and 18th century cadastral maps and aerial photographs. Landscape Ecology, 16, 41-54.

Dewan, A.M., \& Yamaguchi, Y. (2009). Land use and land cover change in Greater Dhaka, Bangladesh: Using remote sensing to promote sustainable urbanization. Applied Geography, 29, 390-401.

Díaz-Pacheco, J., \& Gutiérrez, J. (2013). Exploring the limitations of CORINE Land Cover for monitoring urban land-use dynamics in metropolitan areas. Journal of Land Use Science, http://dx.doi.org/10.1080/1747423X.2012.761736

Dunjó, G., Pardini, G., \& Gispert, M. (2003). Land use change effects on abandoned terraced soils in a Mediterranean catchment, NE Spain. Catena, 52 (1), 23-37.

Dupuy, J.M., González, J.A., Iriarte, S., Calvo, L.M., Espadas, C., Tun, F., \& Dorantes, A. (2007). Cambios de cobertura y uso de suelo (1979-2000) en dos comunidades rurales en el noroeste de Quintana Roo (Changes in land use and cover, 1979-2000, in two rural communities in northwest Quintana Roo). Investigaciones Geográficas. Boletín del Instituto de Geografía UNAM, 62, 104-125.

EEA (2002). Towards an urban atlas. Assessment of spatial data on 25 European cities and urban areas. Luxembourg: Office for Official Publications of the European Communities.

EUROPARC-España. (2013). Anuario 2013 del estado de las áreas protegidas en España. Madrid: Fundación Fernando González Bernáldez, http://www.redeuroparc.org/img/Anuario-2013/ANUARIO2013_EUROPARC_WEB.pdf

Feranec, J., Šúria, M., Ot'ahel', J., Cebecauer, T., Kolář, J., Soukup, T., Zdeňková, D., Waszmuth, J., Vâjdea, V., Vîjdea, A.M., \& Nitica, C. (2000). Inventory of major landscape changes in the Czech Republic, Hungary, Romania and Slovak Republic 1970s-1990s. International Journal of Applied Earth Observation and Geoinformation, 2 (2), 129139.

Feranec, J., Hazeu, G., Christensen, S., \& Jaffrain, G. (2007a). CORINE land cover change detection in Europe (case studies of the Netherlands and Slovakia). Land Use Policy, 24, 234-247

Feranec, J., Hazeu, G., Jaffrain, G., \& Cebecauer, T. (2007b). Cartographic aspects of land cover change detection -over and underestimation in the I\&CORINE Land Cover 2000 project-. The Cartographic Journal, 44, 44-54.

Feranec, J., Jaffrain, G., Soukup, T., \& Hazeu, G. (2010). Determining changes and flows in European landscapes 19902000 using CORINE land cover data. Applied Geography, 30, 19-35

Fernández Güell, J.M. (2008). Condiciones para abordar la ordenación territorial de una región urbana dinámica: el caso de la Comunidad de Madrid (Policies to address spatial planning in a dynamic urban region: the case of the Community of Madrid), I Congreso de Urbanismo y Ordenación del Territorio. Bilbao. Colegio de Ingenieros de Caminos, Canales y Puertos. www.ciccp.es/biblio_digital/Urbanismo_I/congreso/pdf/010301.pdf

Fernández-Muñoz, S. (2008). Participación pública, gobierno del territorio y paisaje en la Comunidad de Madrid (Public participation, goverment planning and landscape in the Community of Madrid). Boletín de la Asociación de Geógrafos Españoles, 46, 97-119. 
Fraser, R.H., Olthof, I., \& Pouliot, D. (2009). Monitoring land cover change and ecological integrity in Canada's national parks. Remote Sensing of Environment.113, 1397-1409.

Gallardo M, Gómez I, Vilar L, Martínez-Vega J., \& Martin P. (2015). Impacts of future land use/land cover on wildfire occurrence in the Madrid region (Spain). Regional Environmental Change. http://dx.doi.org/10.1007/s10113-015$\underline{0819-9}$

Gallardo, M. \& Martínez-Vega, J. (2012). Cambios de usos del suelo en la Comunidad de Madrid: analizando el pasado y simulando el futuro. In J. Martínez-Vega, \& P. Martín, (Eds.) Tecnologías de la información geográfica en el contexto de Cambio Global. (pp. 305-314). Madrid. Asociación de Geógrafos Españoles.

Green, K., Kempka, D. \& Lackey, L. (1994). Using remote sensing to detect and monitor land-cover and land-use change. Photogrammetric Engineering and Remote Sensing, 60 (3), 331-337.

Gulinck, H., Dufourmont, H., Brunovsky, M., Andries, A., \& Wouters, P. (1993). Satellite images for the detection of changes in rural landscapes: a landscape-ecological perspective. EARSeL Advances in Remote Sensing, 2 (3), 84-90.

Gulinck, H., Múgica, M., de Lucio, J.V., \& Atauri, J.A. (2001). A framework for comparative landscape analysis and evaluation based on land cover data, with an application in the Madrid region (Spain). Landscape and Urban Planning, 55 (4), 257-270.

Hewitt, R., \& Escobar, F. (2011). The territorial dynamics of fast-growing regions: Unsustainable land use change and future policy challenges in Madrid, Spain. Applied Geography, 31, 650-667.

Hall, P. \& Pain, K. (2006). The Polycentric Metropolis: Learning from Mega-City Regions in Europe, London, Earthscan.

Hildenbrand, A. (2006). La política de ordenación del territorio de las Comunidades Autónomas: Balance crítico y propuestas para la mejora de su eficacia (Policie planning of Autonomous Communities: assesment and proposals for improving their efficiency). Revista de Derecho Urbanístico y Medio Ambiente, 230, 79-139.

Holbrook, J.A., \& Tudor, G.J. (1993). The use of RemoteSensing and GIS methods for mapping land cover change in Scotland. EARSeL Advances in Remote Sensing, 2 (3), 77-83.

James, K. (2012). An investigation of the relationship between recycling paper and card and greenhouse gas emissions from land use change. Resources, Conservation and Recycling, 67, 44-55.

Kasanko, M., Barredo, J.I., Lavalle, C., McCormick, N., Demicheli, L., Sagris, V., \& Brezger, A. (2006). Are European cities becoming dispersed? A comparative analysis of 15 European urban areas. Landscape and Urban Planning, 77, 11-130.

Lasanta, T., \& Vicente-Serrano, S.M. (2012). Complex land cover change processes in semiarid Mediterranean regions: An approach using Landsat images in northeast Spain. Remote Sensing of Environment, 124, 1-14.

Madrid Census. http://www.madrid.org/iestadis/

MAGRAMA (2015). Banco de datos de la naturaleza. http://www.magrama.gob.es/es/biodiversidad/servicios/bancodatos-naturaleza/

Mallinis, G., Emmanoloudis, D., Giannakopoulos, V., Maris, F. \& Koutsias, N. (2011). Mapping and interpreting historical land cover/land use changes in a Natura 2000 site using earth observational data: The case of Nestos delta, Greece. Applied Geography, 31, 312-320.

Martínez-Fernández, J., Ruiz-Benito, P., \& Zavala, M.A. (2015). Recent land cover changes in Spain across biogeographical regions and protection levels: Implications for conservation policies. Land Use Policy, 44, 62-75.

Martínez-Vega, J., Romero-Calcerrada, R., \& Echavarría, P. (2007). Valoración paisajística y ecológica de la Comunidad de Madrid: su integración en un índice sintético de riesgo de incendios forestales (Landscape and ecological assessment of the Community of Madrid: their integration into a forest fire synthetic index of risk). Revista de Teledetección, 28, 43-60.

Mas, J.F., Velázquez, A., Díaz-Gallegos, J.R., Mayorga-Saucedo, R., Alcántara, C., Bocco, G., Castro, R., Fernández, T., \& Pérez-Vega, A. (2004). Assessing land use/cover changes: a nationwide multidate spatial database for Mexico. International Journal of Applied Earth Observation and Geoinformation, 5, 249-261.Ministerio de Fomento (2015) Atlas digital de las Áreas Urbanas (Digital Atlas of Urban Areas). http://atlas.vivienda.es/, last accessed 06/11/2015. Moliní, F. \& Salgado, M. (2012). Sprawl in Spain and Madrid: A Low Starting Point Growing Fast, European Planning Studies, 20:6, 1075-1092.

Muñoz, F. (2003). Lock living: Urban sprawl in Mediterranean cities. Cities, 20 (6), 381-385.

Naredo, J.M., García Zaldívar, R.C. (2008). Estudio sobre la ocupación de suelo por usos urbano-industriales, aplicado a la Comunidad de Madrid. Ministerio de Medio Ambiente y Universidad Politécnica de Madrid.

Peña, J., Bonet, A., Bellot, J., Sánchez, J.R., Eisenhulth, D., Hallett, S., \& Aledo, A. (2007). Driving forces of land-use change in a cultural landscape of Spain. In E. Koomen, J. Stillwell, A. Bakema, \& H.J. Scholten, (Eds.), Modelling land-use change. Progress and applications (pp. 97-115). Springer.

Pérez-Hugalde, C., Romero-Calcerrada, R., Delgado-Pérez, P., \& Novillo, C. J. (2011). Understanding land cover change in a Special Protection Area in Central Spain through the enhanced land cover transition matrix and a related new approach. Journal of Environmental Management, 92(4), 1128-1137.

Plata Rocha, W., Gómez Delgado, M., \& Bosque Sendra, J. (2009). Cambios de usos del suelo y expansión urbana en la Comunidad de Madrid 1990-2000 (Changes in land use and urban expansión in the Community of Madrid, 19902000). Scripta Nova, 13 (293), http://www.ub.es/geocrit/sn/sn-293.htm (accessed Oct. 2014). 
Plata Rocha, W., Gómez Delgado, M. \& Bosque Sendra, J. (2010). Desarrollo de modelos de crecimiento urbano óptimo para la Comunidad de Madrid aplicando métodos de evaluación multicriterio y Sistemas de Información Geográfica (Development of optimal urban growth models in the Community of Madrid applying multicriteria evaluation methods and Geographic Information Systems). Geofocus. 10, 103-134.

Pontius Jr, R.G., Shusas, E., \& McEachern, M. (2004). Detecting important categorical land changes while accounting for persistence. Agriculture, Ecosystems and Environment, 101, 251-268.

Rodríguez-Rodríguez, D., \& Martínez-Vega, J. (2013). Results of the implementation of the System for the Integrated Assessment of Protected Areas (SIAPA) to the protected areas of the Autonomous Region of Madrid (Spain). Ecological Indicators, 34, 210-220.

Rodríguez-Rodríguez, D., \& Martínez-Vega, J. (under review). What should be evaluated from a manager's perspective? Developing a salient protected area effectiveness evaluation system by managers and scientists. Ecological Indicators.

Román, M.V., Azqueta, D., \& Rodrigues, M. (2013). Methodological approach to assess the socio-economic vulnerability to wildfires in Spain. Forest Ecology and Management, 294, 158-165.

Romero-Calcerrada, R., \& Perry, G.L.W. (2004). The Role of Land Abandonment in Landscape Dynamics in the SPA 'Encinares del río Alberche y Cofio' Central Spain, 1984-1999. Landscape and Urban Planning, 66 (4), $217-232$.

Romero-Calcerrada, R., Martínez de Anguita, P., Pascual, C., Ruiz, M.A., Gómez, I., Beneitez, J.M., \& Montero, J. (2005). Cultural Landscape Unit definition as integrated decision making tool for Sustainable Regional Planning. Proceedings of International Conference Multifunctionality of Landscapes. Analysis, Evaluation and Decision Support. Giessen.

Ruiz Benito, P., Cuevas, J.A., Bravo de la Parra, R., Prieto, F., García del Barrio, J.M., \& Zavala, M.A. (2010). Land Use change in a Mediterranean metropolitan region and its periphery: assessment of conservation policies through CORINE Land Cover data and Markov models. Forest Systems, 13 (3), 315-328.

Serra, P., Vera, A., Tulla, A.F., \& Salvati, L. (2014) Beyond urban-rural dichotomy: Exploring socioeconomic and landuse processes of change in Spain (1991-2011). Applied Geography, 55, 71-81.

Shalaby, A., \& Tateishi, R. (2007). Remote sensing and GIS for mapping and monitoring land cover and land-use changes in the Northwestern coastal zone of Egypt. Applied Geography, 27, 28-41.

Turner, M.G., O'Neill, R.V., Gardner, R.H., \& Milne B.T. (1983). Effects of changing spatial scale on the analysis of landscape pattern. Landscape Ecology, 3, 153-162.

Valenzuela, M. (2011). La planificación territorial de la región metropolitana de Madrid. Una asignatura pendiente (Territorial planning of Madrid metropolitan area. An unresolved issue). Cuadernos Geográficos, 47 (2010-2), 95129.

Vilar, L., Martín, M.P., \& Martínez-Vega, J. (2011). Logistic regression models for human-caused wildfire risk estimation: analysing the effect of the spatial accuracy in fire occurrence data. European Journal of Forest Research, 130, 983-996

Wu, Q., Li, H.Q., Wang, R.S., Paulussen, J., He, Y., Wang, M., Wang, B.H., \& Wang, Z. (2006). Monitoring and predicting land use change in Beijing using remote sensing and GIS. Landscape and Urban Planning, 78, 322-333.

Xiao, J., Shen, Y., Ge, J., Tateishi, R., Tang, C. Liang, Y., \& Huang, Z. (2006). Evaluating urban expansion and land use change in Shijiazhuang, China, by using GIS and remote sensing. Landscape and Urban Planning, 75, 69-80.

Zhang, H., Qi, Z.F., Ye, X.Y., Cai, Y.B., Ma, W.C., \& Chen, M.N. (2013). Analysis of land use/land cover change, population shift, and their effects on spatiotemporal patterns of urban heat islands in metropolitan Shanghai, China. Applied Geography, 44, 121-133. 